\title{
2 軸曲げを受けるコンクリート充填角形鋼管長柱の耐力予測 DESIGN FORMULA OF A LONG CONCRETE-FILLED TUBE SUBJECTED TO BI-AXIAL BENDING
}

\author{
柴田道生* \\ Michio SHIBATA
}

\begin{abstract}
Theoretical studies are presented on the prediction of bending strength of a long concrete-filled rectangular tube subjected to bi-axial bending. The main objective of this study is to refine the AIJ design formula which is based on the modified superposed strength method. Sophisticated moment magnification factor is introduced, which can be applied to long columns subjected to non-sym netric bi-axial bending. Bending strength of a long column is calculated as the full plastic moment, which is obtained by the generalized-superposed strength method, divided by the moment magnification factor. Proposed formula shows a good agreement with precise numerical solutions.
\end{abstract}

Keywords : composite column, concrete-filled tube, bi-axial bending, maximum strength, design formula, moment magnification factor CFT 長柱, 非対称 2 軸曲げ, 最大耐力, 設計式, モーメント拡大係数

\section{1 序}

文献 1)の提案に基づく，日本建築学会・鉄骨鉄筋コンクリート（以 下 SRC）構造計算規準 2)の長柱規定は 1 軸曲げ部材のみを対象として いる. 最近の合成長柱の設計式に関する一連の研究 3-8)も 1 軸曲げの みを対象としており，2 軸曲げを受ける合成長柱の設計式は未だ提案さ れていない. また, それらの 1 軸曲げの提案式も両端の材端モーメン トの等しい対称曲げのみを検討対象とし, 非対称曲げに対しては等価 曲げモーメント係数を応用するとしているが, 文献 9)等で提案されて いる等価曲げモ一メント係数は必ずしも精度が良くない.

本研究は，断面構成が単純な長方形コンクリート充填鋼管（以後 CFT）に対象を絞り, 弾性梁一柱（beam-column）理論の結果を拡張し て2軸曲げを受けた場合の耐力予測式を導く.

\section{2 基本仮定と検討対象}

\section{1 仮定}

1) 一定軸力 $N$ と, 両端に大きさは異なるが作用方向の等しい 2 軸曲げ材 端モーメント $M_{d}$ および $\alpha M_{d}(-1 \leq \alpha \leq 1)$ を受ける単純梁を検討対 象とする (Fig.1 参照)，中間荷重は存在しない，節点移動を生じる部 材については，移動後の節点間を結ぶ部材について本論を適用する.

2) 部材は長方形角形鋼管にコンクリートを充填した CFT 部材とする 3) コンクリートは $F_{c}=330 \sim 800 \mathrm{~kg} / \mathrm{cm}^{2}$ 程度の強度を持ち, コンファイ
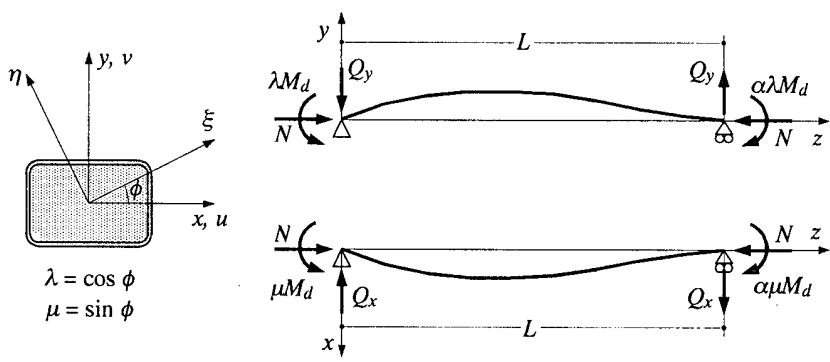

Fig.1 Beam-column subjected to bi-axial bending

ン効果および引張強度を期待しない.

4) 鋼管の降伏応力は $\sigma_{y}=3.3 \sim 8 \mathrm{t} / \mathrm{cm}^{2}$ 程度 を想定し，板要素の局部座屈は生じない. 高強度鋼の使用は高強度コンクリートと の組み合わせをげ原則とする.

5) 材料の応力ーひずみ関係は Fig.2 に示すパ ラボラ型とする. 比例限度 $r$ は通常の鋼材 では 0.6 1 程度, 熱残留応力や塑性加工に よる残留応力が存在する鋼材では $0.2 \sim$ 0.6 程度と予想される. 本論で扱う鋼材を

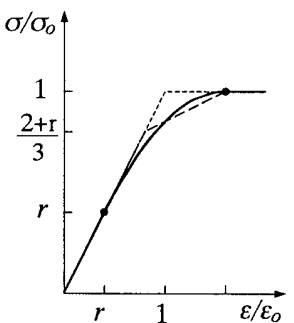

Fig.2 Parabolic stress -strain relationship 冷間成型角形鋼管とし, 鋼材の比例限を $r=0.3$ とする. また, コンク リートでは $r=0$ とする. 
Table 1 Examples

\begin{tabular}{cccccc}
\hline Example No. & 1 & 2 & 3 & 4 & 5 \\
\hline$F_{c}\left(\mathrm{t} / \mathrm{cm}^{2}\right)$ & 0.33 & 0.33 & 0.33 & 0.80 & 0.80 \\
$\sigma_{y}\left(\mathrm{t} / \mathrm{cm}^{2}\right)$ & 3.3 & 3.3 & 3.3 & 3.3 & 8.0 \\
$A_{s} / A_{c}$ & 0.065 & 0.10 & 0.15 & 0.10 & 0.10 \\
$N_{o s} / N_{o c}$ & 0.65 & 1.00 & 1.50 & 0.41 & 1.00 \\
$M_{\text {xos }} / M_{\text {xoc }}$ & 2.12 & 3.29 & 5.00 & 1.36 & 3.29 \\
\hline
\end{tabular}
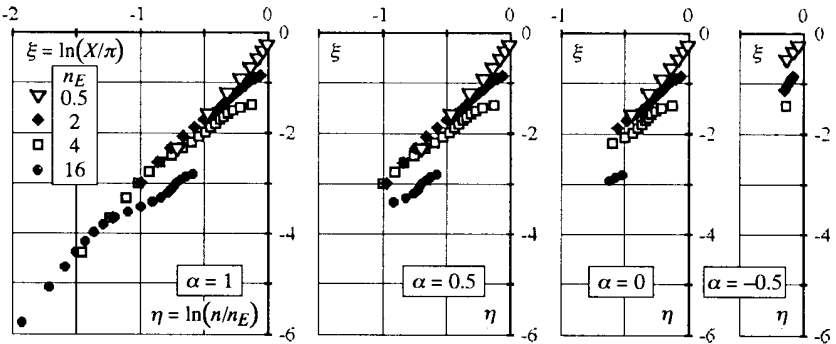

(a) Example $2 \quad \phi=0^{\circ}$
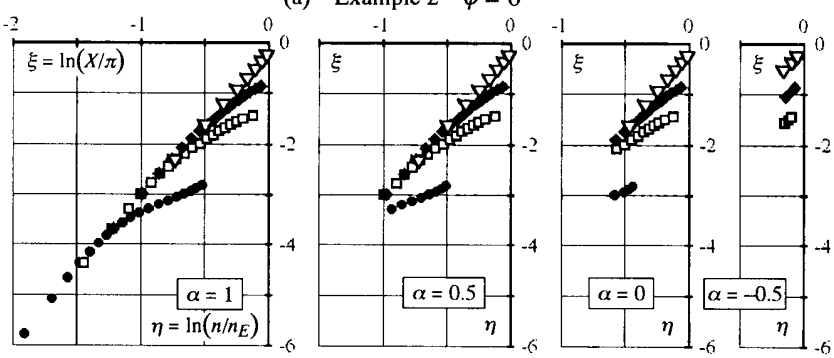

(b) Example $2 \quad \phi=45^{\circ}$
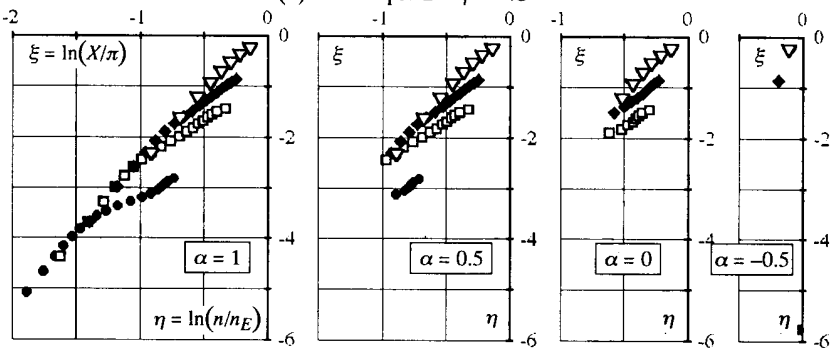

(c) Example $2 \phi=90^{\circ}$
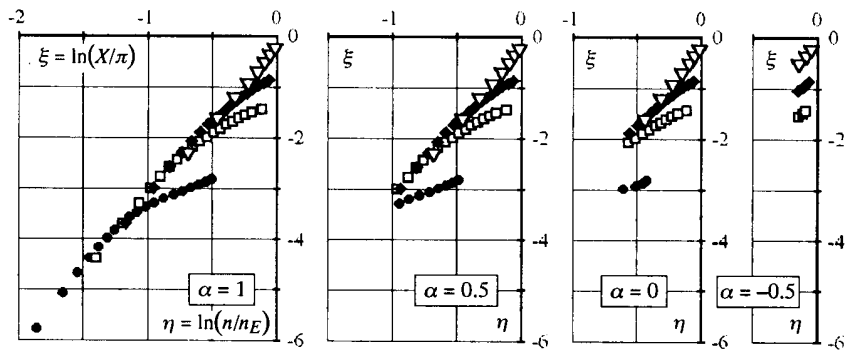

(d) Example $4 \quad \phi=45^{\circ}$
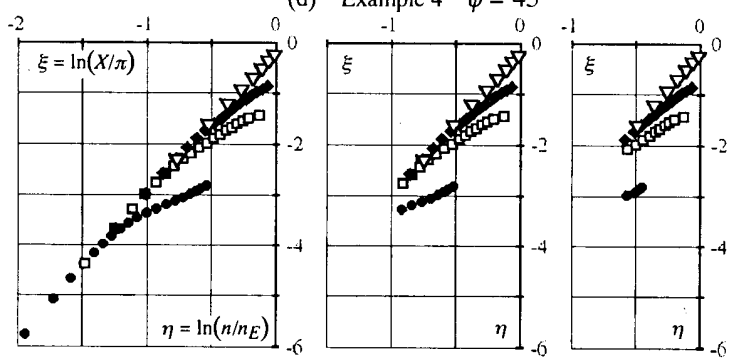

(e) Example $5 \quad \phi=45^{\circ}$

Fig.3 $\ln (X / \pi)-\ln \left(n / n_{E}\right)$ relationships

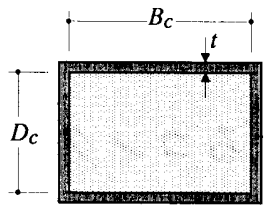

Fig.4 Rectangular CFT

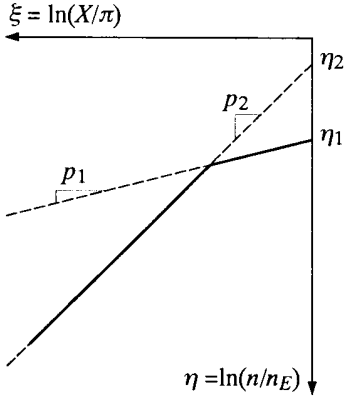

Fig.5 Bi-liniar approximation

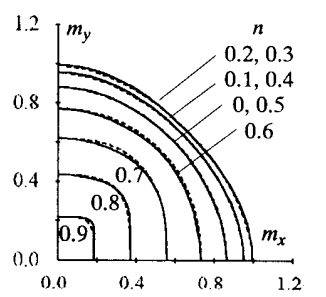

(a) $M_{x} / M_{x o}-M_{y} / M_{y o}$

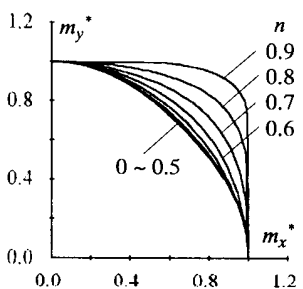

(b) $M_{x} / M_{x p}-M_{y} / M_{y p}$

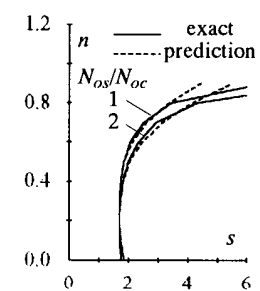

(c) $N / N_{o}-s$

Fig.6 Full plastic theory

\section{2 検討対象と適用範囲}

冷間成形角形鋼管を用いた CFT 柱の, 鋼材とコンクリートの断面積 比はおおよそ $A_{S} / A_{c}=0.06 \sim 0.15$ の範囲にあり, 仮定 4), 5)より Table 1 の 5 例題について検討を進める. 表中の $N_{o S}, N_{o c}$ および $M_{x o s}, M_{x o c}$ は 鋼材とコンクリートの降伏軸力および基準弱軸曲げ強度（中立軸が断 面中心を通るときの全塑性モーメント) である.

例題 2,4,5 は鋼材とコンクリートの断面積比が平均的な値の場合, 例 題 1 は下限の, 例題 3 は上限の值に相当する. 使用材料は, 例題 $1 \sim 3$ は普通コンクリートと軟鋼, 例題 4 は高強度コンクリートと軟鋼, 例 題 5 は高強度材料同士の組み合わせである.

\section{3 耐力評価式}

軸力 $N$ のもとで $\phi$ 軸回り（Fig.1 参照）の 2 軸曲げを受ける長柱の曲 げ耐力 $M_{d}(N, \phi)$ を, 全塑性理論に基づく 2 軸曲け耐力 [全塑性モ一メ ント] $M_{p}(N, \phi)$ を一メント拡大係数 $\mu$ で除して与える.

$$
M_{d}(N, \phi)=M_{p}(N, \phi) / \mu
$$

\section{1 モーメント拡大係数}

非対称曲げを受ける SRC 長柱のモーメント拡大倸数を, 弾性梁一柱 理論結果 9)に準じて次式で与える.

$$
\begin{gathered}
\mu=\sqrt{1+\left\{\frac{\alpha-\cos X}{\sin X}\right\}^{2}} \\
X=\pi(n / q)^{p} / \omega
\end{gathered}
$$

ここに, $n=N / N_{o}$ は作用軸力と降伏軸力の比であり, 定数 $p, q$ は材 端モーメント比 $\alpha$, 無次元 Euler 荷重 $n_{E}$ および断面形状に依存する 形状係数 :

$$
\rho_{s}=\left(\frac{\sum \sigma_{y i} Z_{x p i}}{\sum N_{o i}}\right)^{2} / \frac{\sum E_{x i} I_{i}}{\sum E_{i} A_{i}}
$$

構成法則に依存する 材料特性係数 :

$$
\rho_{m}=\sum\left(\rho_{m i} M_{o i}\right) / \sum M_{o i}
$$

などの関数と見なせる.

一方 2 軸曲げ効果を規定する定数 $\omega$ は弱軸曲げを $\omega=1$ とし, 強軸と 
弱軸に関する断面 2 次モーメント $I_{x}, I_{y}$ および材端モ一メント軸が 断面弱軸となす角度 $\phi$ (以後, 載 荷角度）に依存すると考えられる。 ここに, $\rho_{m i}$ は各構成要素材料の 比例限度 $r_{i}$ （Fig.2参照）より

$$
\rho_{m i}=\left(2+r_{i}\right) / 3
$$

で定義される $i$ 要素の応力ーひず み曲線の特性係数, $\sigma_{y i}, Z_{x p i}, N_{o i}$, $E_{i}, A_{i}, I_{x i}$ は各構成要素の降伏応 力, 弱軸曲け塑性断面形数, 降伏 軸力, Young 係数, 断面積および 弱軸まわり断面 2 次モ一メントで あり, $M_{o i}$ は基準弱軸曲げ強度 (中 立軸が断面中心を通るときの全 塑性モーメント) である.

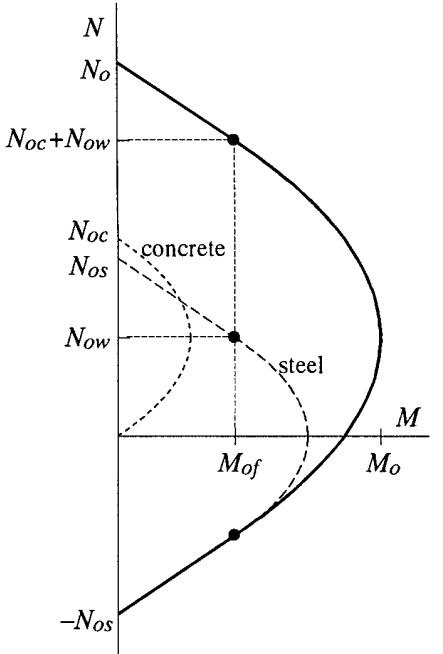

Fig.7 Full plastic moment for principal axis bending.
式(2)を変形すると次式を得る.

$$
X=\tan ^{-1}\left(\frac{\alpha \sqrt{\mu^{2}-a^{2}}-\sqrt{\mu^{2}-1}}{\mu^{2}-1-\alpha^{2}}\right)
$$

Fig.3 は $D_{c} / B_{c}=2 / 3, N_{o c} / N_{o s}=1, \sigma_{y}=3.3 \mathrm{t} / \mathrm{cm}^{2}, F_{c} / \sigma_{y}=0.1$ (Fig.4 参 照) の場合について, 精密な数值解析 10)より得られたモーメント拡大 係数 $\mu$ (存在軸力に対応した全塑性モーメントと最大材端モーメント の比)より式(4)で求めた $X$ と軸力比の関係を雨対数表示したものであ り, 両軸は

$$
\xi=\ln (X / \pi), \quad \eta=\ln \left(n / n_{E}\right)
$$

を表す．完全弾塑性サンドイッチ断面材ではこの関係は常に

$$
\xi=\eta / 2
$$

で表されるので, 式(6)と Fig.3 との差異が断面形状や構成則の影響を表 すことになる.ここに, $B_{c}, D_{c}$ はコンクリート部の幅とせいである.

Fig.3(a)は材端モーメント軸と断面弱軸のなす角度が $\phi=0^{\circ}$ の場合で あり,これらの関係は Fig.5 のバイリニア型で近似することが可能であ $り$, 第 1,2 折机線の公配 $p_{1}, p_{2}$ および $\eta$ 軸との交点 $\eta_{1}, \eta_{2}$ は, 部材 の接線係数荷重と降伏軸力の比を $n_{c r}$ とおけば, 次式で評価することが できる.

$$
\begin{aligned}
& p_{2}=\frac{c(\alpha)}{2}\left(1-\frac{1}{2} \sqrt[4]{1-\rho_{s}}\right) \\
& c(\alpha)=\sqrt{1-\left(0.3-0.15 \rho_{s}\right)(1-\alpha)^{2}} \\
& p_{1}=1.6 p_{2} \sqrt{n_{E}} \\
& \eta_{1}=\ln \left\{n_{c r} / n_{E}\right\} \\
& \eta_{2}=\rho_{m}-1
\end{aligned}
$$

同図(b), (c)は $\phi=45^{\circ}, 90^{\circ}$ の場合であるが, $\phi=0^{\circ}$ の場合之同様の傾向 を示し， $\phi$ の影響 $\omega$ は次式で評価することができる.

$$
\omega=1+\left\{\sqrt[4]{(E I)_{y} /(E I)_{x}}-1\right\}\left(\frac{\phi}{\pi / 2}\right)^{2}
$$

ここに, $(E I)_{x}=\sum E_{i} I_{x i}$ および $(E I)_{y}=\sum E_{i} I_{y i}$ は各断面構成要素の 弱軸および強軸まわりの曲け剛性の和である.

\section{2 全塑性モーメントの評価}

Fig.6(a)の実線は圧縮強度比 $N_{o c} / N_{o s}=1$, 縦横比 $D_{c} / B_{c}=0.5$ の場合 の全塑性理論による 2 軸曲げ耐力相関曲線を示し, 両軸は弱軸および 強軸まわりの基準曲げ強度 $M_{x o}$ および $M_{y o}$ で無次元化されている. 同
図において曲げ耐力の $x, y$ 成分 $M_{x}(N, \phi), M_{y}(N, \phi)$ をそれぞれ作用軸 カに対応した主軸曲げ全塑性モーメント $M_{x p}(N), M_{y p}(N)$ で無次元化 すると Fig.6(b)の実線を得る．これらの曲線群は $45^{\circ}$ 軸に関してほぼ 対称であり,

$$
\begin{aligned}
& \left(m_{x}^{*}\right)^{s}+\left(m_{y}^{*}\right)^{s}=1 \\
& \quad m_{x}^{*}=\frac{M_{x}(N, \phi)}{M_{x p}(N)}, \quad m_{y}^{*}=\frac{M_{y}(N, \phi)}{M_{y p}(N)}
\end{aligned}
$$

で近似するなら, $45^{\circ}$ 方向の半径 $m_{45}^{*}$ とべき乗数 $s$ の間には次式

$$
s=\ln 2 / \ln \left(m_{45}^{*} / \sqrt{2}\right)
$$

が成立する. Fig.6(c)の実線は数值解析で得られた $m_{45}^{*}$ に基づく $s$ と 軸力比の関係を示し, 破線は次式による近似を示す.

$$
s=10 \times\left|N / N_{o}-0.35+0.075 N_{o s} / N_{o c}\right|^{3}+1.7
$$

式(11)を式(9)に代入して得られる関係を Fig.6(a)中に破線で示す. 近 似度はきわめて良好である.

式(9)により全塑性モーメントを得るためには, 主軸まわりの全塑性 モーメント $M_{x p}(N), M_{y p}(N)$ を求める必要がある. 角形 CFT の主軸曲 げ強度は，コンクリート，鋼管フランジおよび鋼管ウェブの降伏軸力 および基準曲げ強度を $N_{o c}, N_{o f}, N_{o w}$ および $M_{o c}, M_{o f}, M_{o w}$ とすれば, 次式で評価することができる（Fig.7 参照).

$$
\begin{aligned}
& N>N_{o c}+N_{o w}: \quad M_{p}(N)=M_{o f}\left(1-\frac{N-N_{o c}-N_{o w}}{N_{o f}}\right) \\
& N<N_{o c}+N_{o w}: \\
& \quad M_{p}(N)=M_{o f}+\left(M_{o c}+M_{o w}\right)\left\{1-\left(\frac{2 N-N_{o c}}{N_{o c}+2 N_{o w}}\right)^{2}\right\}
\end{aligned}
$$

\section{3 接線係数荷重の評価}

式(7d)では部材の接線係数荷重が必要となる. 合成部材の接線係数荷 重は各構成要素の接線係数荷重の和で良好に近似できることが知られ ている 1). Fig.2 の構成則に従う $i$ 要素の接線係数荷重と降伏荷重の比 $n_{c r i}$ は, 各要素の無次元 Euler 荷重を $n_{E i}$ とおけば, 次式で与えられ,

$$
n_{c r i}= \begin{cases}n_{E i} & n_{E i} \leq r_{i} \\ \frac{\sqrt{4\left(1-r_{i}\right) / n_{E i}^{2}+1}-1}{2\left(1-r_{i}\right) / n_{E i}^{2}} & n_{E i}>r_{i}\end{cases}
$$

部材としての接線係数荷重 $N_{c r}$ は次式による.

$$
N_{c r}=\sum n_{c r j} N_{o j}=n_{c r c} N_{o c}+n_{c r s} N_{o s}
$$

式(13b)はコンクリートと鋼材の見かけの降伏ひずみ $F_{c} / E_{c}, \sigma_{y} / E_{s}$ が ほぼ等しい場合は良好な近似を与える。しかし，普通コンクリートと 高強度鋼の組み合わせのように，両者の降伏ひずみが相当異なる場合 には危険側の評価を与える可能性がある. Fig.1 の第 1 折れ線は，その 縦軸の切片 $\eta_{1}$ が部材の接線係数荷重に依存するので（式(7d)参照), こ のような場合は本論の適用外亡する（仮定 5)参照）。

\section{4 耐力評価式}

同一構面内の両端で異なった大きさの材端モーメントを受ける CFT 長柱の軸力 $N$ に対する曲げ強度 $M_{d}(N, \phi)$ は, 全塑性理論に基づく極短 柱曲げ強度 $M_{p}(N, \phi)$ をモーメント拡大係数 $\mu$ で除することによって 求められる.

$$
M_{d}(N, \phi)=M_{p}(N, \phi) / \mu
$$



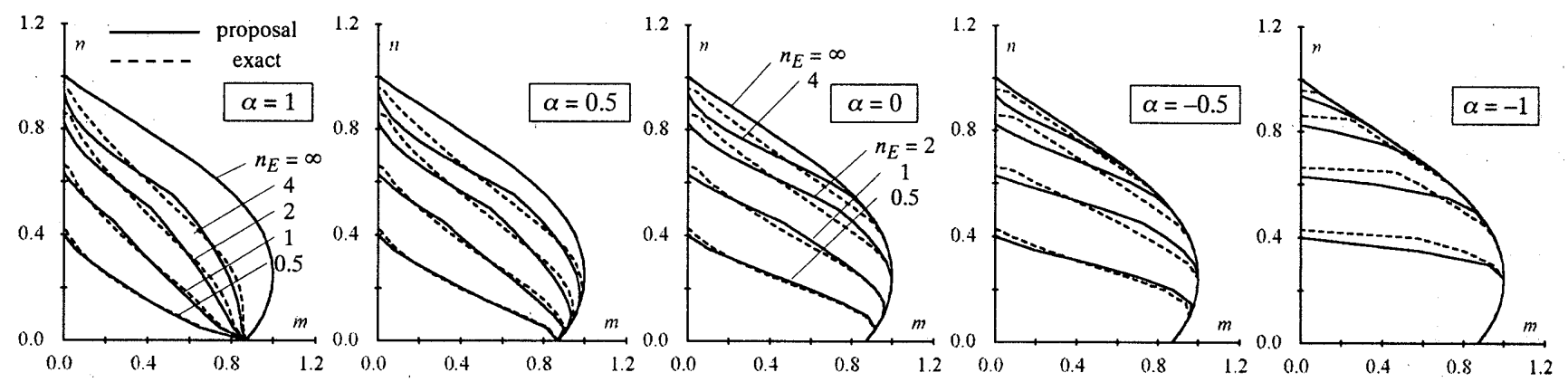

(a) Example $2 \quad \phi=0^{\circ}$
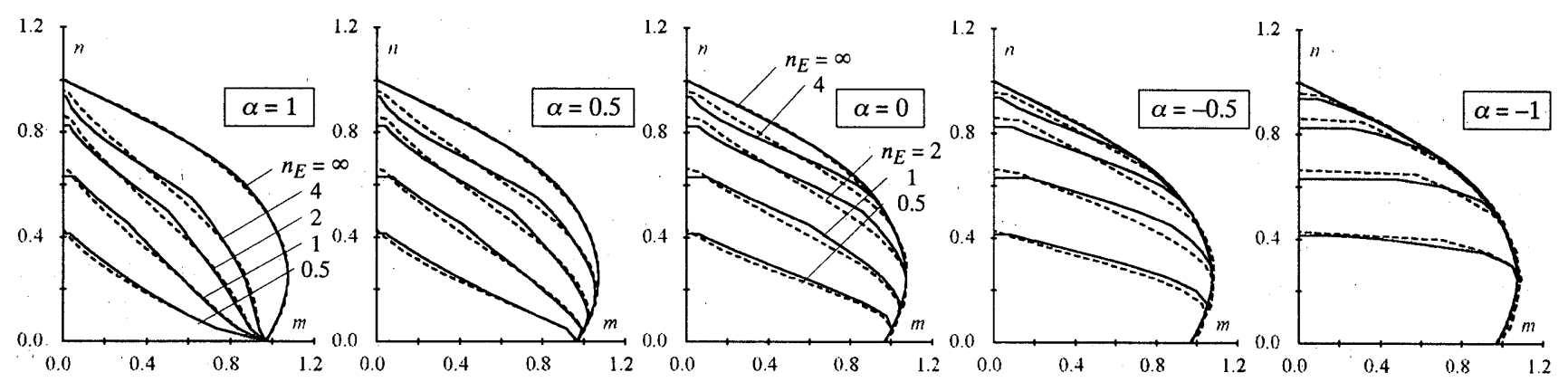

(b) Example $2 \quad \phi=45^{\circ}$
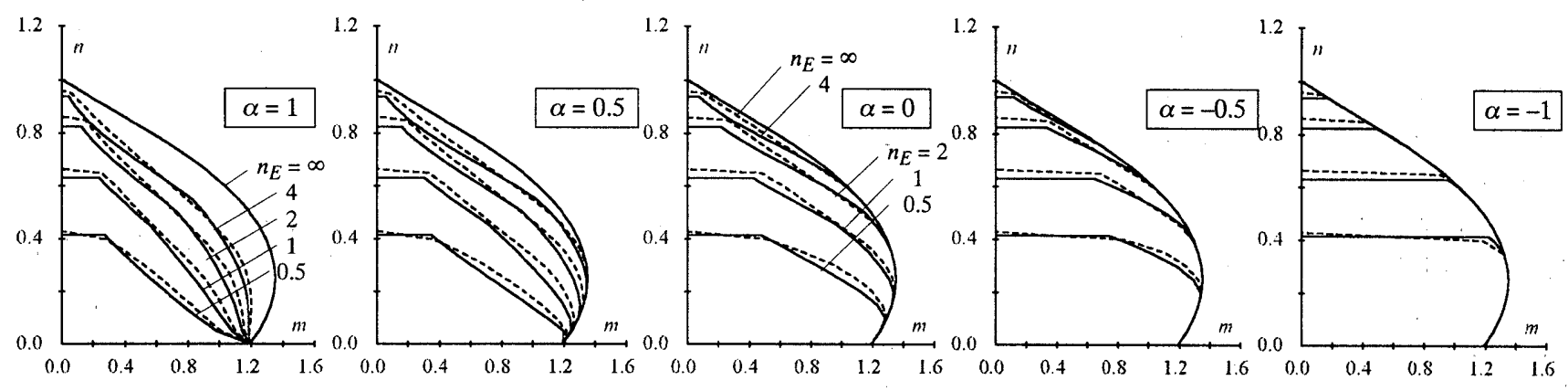

(c) Example $2 \quad \phi=90^{\circ}$
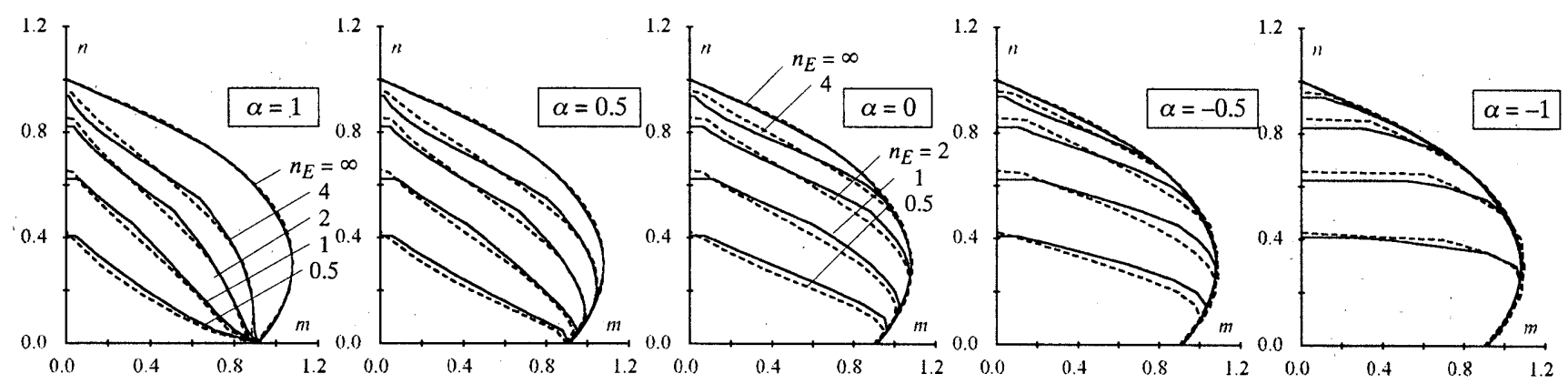

(d) Example $1 \quad \phi=45^{\circ}$
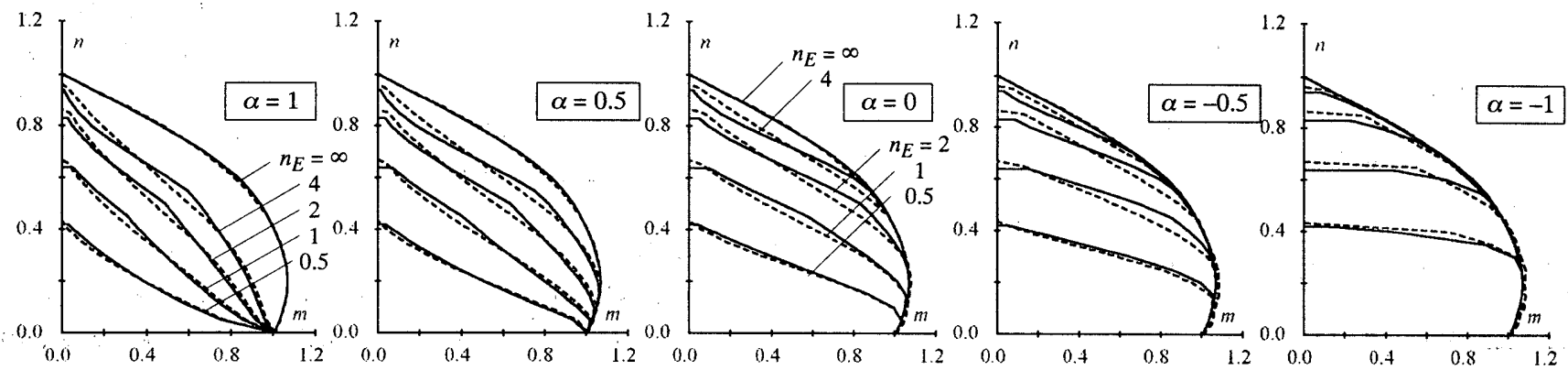

(e) Example $3 \quad \phi=45^{\circ}$

Fig.8 Comparison between proposed formula and exact solutions ( Example 1 $\sim 3$ ) 

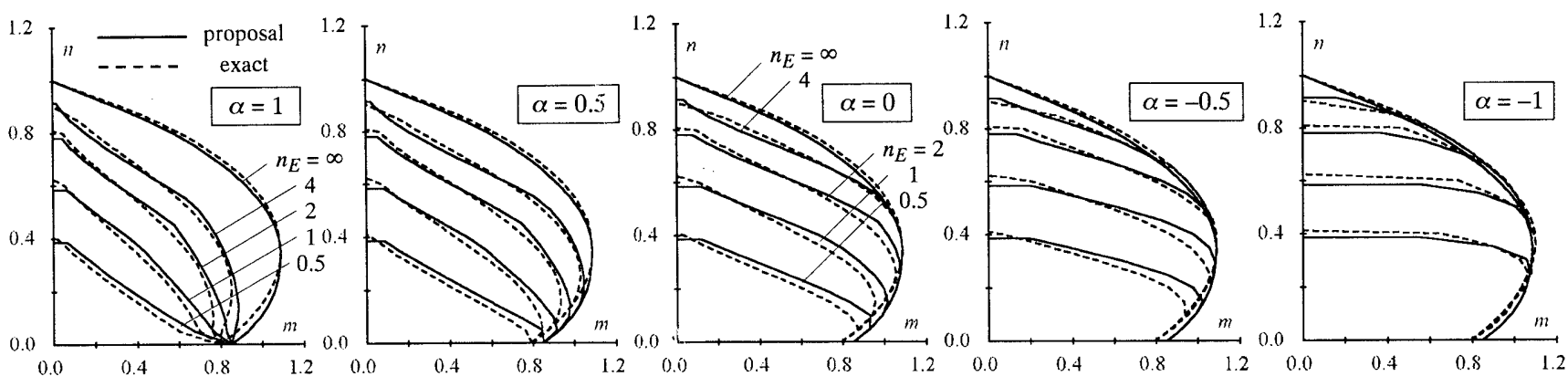

(a) Example $4 \quad \phi=45^{\circ}$
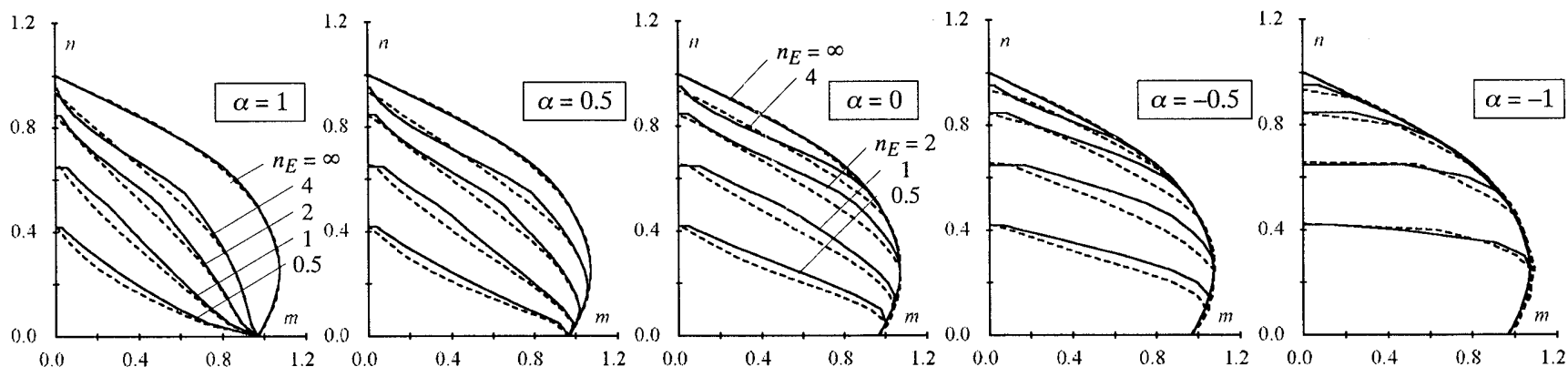

(b) Example $5 \quad \phi=45^{\circ}$

Fig.9 Comparison between proposed formula and exact solutions ( Example 4, 5)

ここに $\mu$ は式(2)の代わりに $\alpha=-1$ での安全率を確保するため、式(2)を 少し修正した次式で与え，

$$
\begin{aligned}
& \mu=\sqrt{1+\left\{\frac{0.1+0.9 \alpha-\cos X}{\sin X}\right\}^{2}} \\
& X=\pi \exp (\xi / \omega) \\
& \quad \xi=\max \left\{p_{1}\left(\eta-\eta_{1}\right), p_{2}\left(\eta-\eta_{2}\right), p_{3} \eta+\xi_{3}\right\}
\end{aligned}
$$

係数 $p_{1}, p_{2}, \eta_{1}, \eta_{2}$ および $\omega$ は式(7), (8)に, 部材の接線係数荷重と 降伏荷重の比 $n_{c r}$ は式(13)による.

2 軸曲げ極短柱曲げ強度 $M_{p}(N, \phi)$ は次式

$$
M_{p}(N, \phi)=1 / \sqrt[s]{\left\{\frac{\cos \phi}{M_{x p}(N)}\right\}^{s}+\left\{\frac{\sin \phi}{M_{y p}(N)}\right\}^{s}}
$$

で評価され，べき乗 $s$ は式(11)に，主軸曲げ強度 $M_{x p}(N), M_{y p}(N)$ は式(12)による.

\section{4 予測精度の検討}

\section{$4.1 N-M$ 相関曲線}

式(14)によって予測した CFT 長柱の曲げ耐力と精密な数值解 10)の比 較例を Fig.8, 9 に示す. 図中の実線は提案式，破線は精密解である.

Fig.8(a) (c)は，例題 2（Table 1 参照）について，載荷角度を部材断面 弱軸に対して $\phi=0,45^{\circ}, 90^{\circ}$ としたときの比較を, Fig.8(d), (e)および Fig.9 は, 45 度曲げに対する例題 1,3〜5の結果を示す.

載荷角度 $\phi$, モ一メント比 $\alpha$, 無次元 Euler 荷重 $n_{E}$, 軸耐力比 $N_{o c} / N_{O S}$, 材料強度 $F_{c}, \sigma_{y}$, によらず, 予測式は精密解と良好な対灾を示すが, 高強度材料を用いた例題 4, 5 では危険側誤差が若干大きくなる.

\section{2 誤差評価}

通常 $N-M$ 相関曲線の誤差評価は, 同一軸力比における横軸の差 （Fig.10(a)）あるいは座標原点からの半径の差（Fig.10(b)）などで評価 される.しかし，2曲線の近接度を評価するには, 曲線の法線方向の距 離で評価すべきである（Fig.10(c)）.
このような評価基準に基づく誤差の分布を Figs.11, 12 に示す. 誤差の 大きさは $N-M$ 相関曲線を降伏軸力および基準曲げ強度で無次元化し たとき, 無次元化空間の 2 曲線の間隔に相当し, 正值が危険側, 負值 が安全側誤差を琵す。

Fig.11 は例題 2 について載荷角度の影響を検討した結果で, 最大誤差 は危険側 4\%程度, 安全側で 6\%程度である. 特に 90 度曲げ (強軸曲げ) では危険側誤差がほとんと生じていない.

Fig.12 は例題 1,3～4 についてコンクリートと鋼管の強度比に着目し た検討を示す．高強度鋼を用いた例題 4 で幾分危険側誤差が大きくな る傾向があるが, 最大䛊差は危険側, 安全側とも $6 \%$ 程度である.

\section{5 結論}

1)非対称 2 軸曲げを受けるコンクリート充填角形鋼管長柱の曲げ而力予 測式を導いた. 計算手順は従来の長柱累加型に比べて非常に単純であ り，非対称曲げについても精度良く予想できる.

2)非対称 2 軸曲げを受ける長柱の曲け耐力は, 全塑性理論に基づく 2 軸 曲げ強度（全塑性モーメント）をモーメント拡大係数で除することに より求められる.

3)存在軸力に対応した 2 軸曲げ強度は，一般化累加強度理論による主軸 曲け強度を用いて求められる。

4) モ一メント拡大係数は, 軸力 $N$, 載荷角度 $\phi$, 材端モ一メント比 $\alpha$, 断面の形状に依存する係数 $\rho_{S}$, 材料の構成法則に依存する係数 $\rho_{m}$,

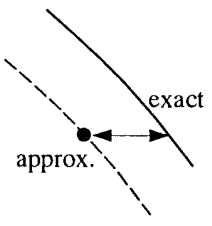

(a) Horizontal difference

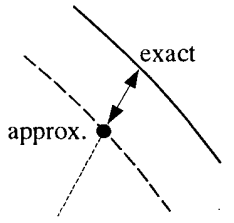

(b) Radial difference

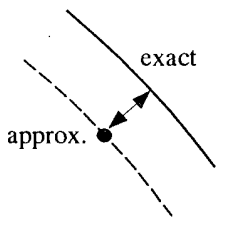

(c) Normal difference
Fig. 10 Error estimation 

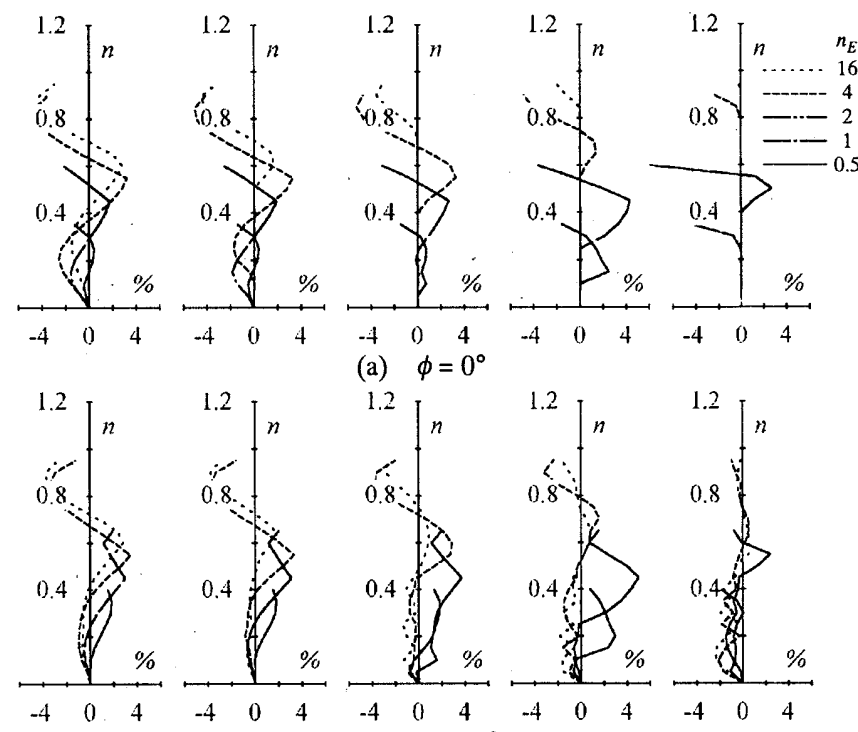

(a) $\phi=0^{\circ}$
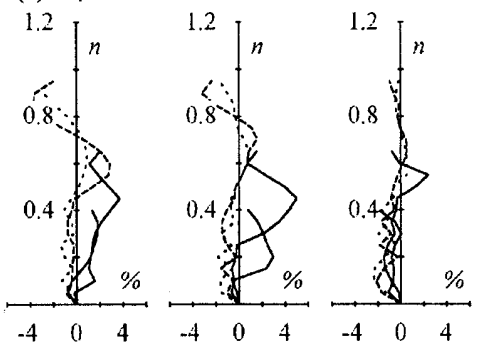

(b) $\phi=45^{\circ}$
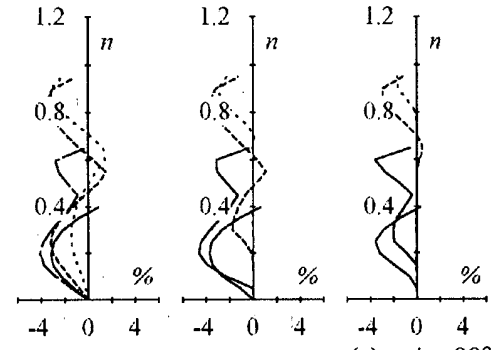

(c) $\phi=90^{\circ}$

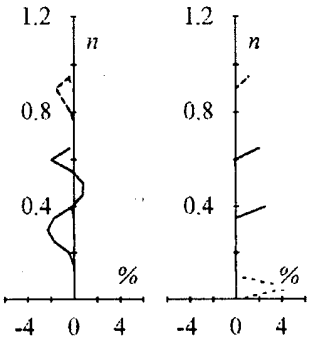

Fig.11 Error estimation

Example 2

Euler 荷重 $N_{E}$ および接線係数荷重 $N_{c r}$ の単純な関数として与えられる. 5)載荷角度，材端モ一メント比，材料強度によらず，予測式は精密解と 良好な対応を示し，一部の例外を除いてその際大誤差は危険側，安全 側とも 6\%程度である.

\section{参考文献}

1)若林 實・吉田 望: 細長い合成柱の設計式, 日本建築学会論文報告 集, No.278, pp.27-36, 1979.04 .

2)日本建築学会 : 鉄骨鉄筋コンクリート構造計算規準・同解説, 1987.

3) 津田恵吾・松井千秋・石橋靖夫 : コンクリート充填鋼管柱の耐力評価 式，日本建築学会構造系論文集，No.496，pp.119-126，1997.06.

4) 津田恵吾・松井千秋 : コンクリート充填鋼管柱の累加耐力評価に用い るコンクリート柱の耐力, 鋼構造論文集, Vol.3, No.10, pp.39-48, 1996.06. 5)柴田道生:SRC 長柱の累加型耐力予測式, 日本建築学会構造系論文集, No.522, pp.121-128, 1999.08 .

6) 藤永 隆, 津田恵吾, 松井千秋: 種々の形状の鉄骨を内蔵する SRC 長柱の耐力, 日本建築学会大会学術講演梗概集, Vol.C-1, pp.1135-1136, 1999.09.

7) 柴田道生:SRC 梁一柱の耐力評価式, 構造工学論文集 (日本建築学会), Vol.40B, pp.351-358, 1994.03 .

8) 佐藤孝典 : CFT 構造の短柱から長柱までの*簡単な設計式の提案, 日 本建築学会大会学術講演梗概集, Vol.C-1, pp.1279-1280, 1999.09.

9) 日本建築学会 : 鋼構造塑性設計指針 6.3 節, p.114 , 1975 .

10) 柴田道生 : 非対称曲げを受ける SRC 長柱の耐力, 日本建築学会大会 学術講演梗概集, Vol.C-1, pp.1139-1140, 1999.09.

11) 日本建築学会 : 鋼構造設計規準, 1970.
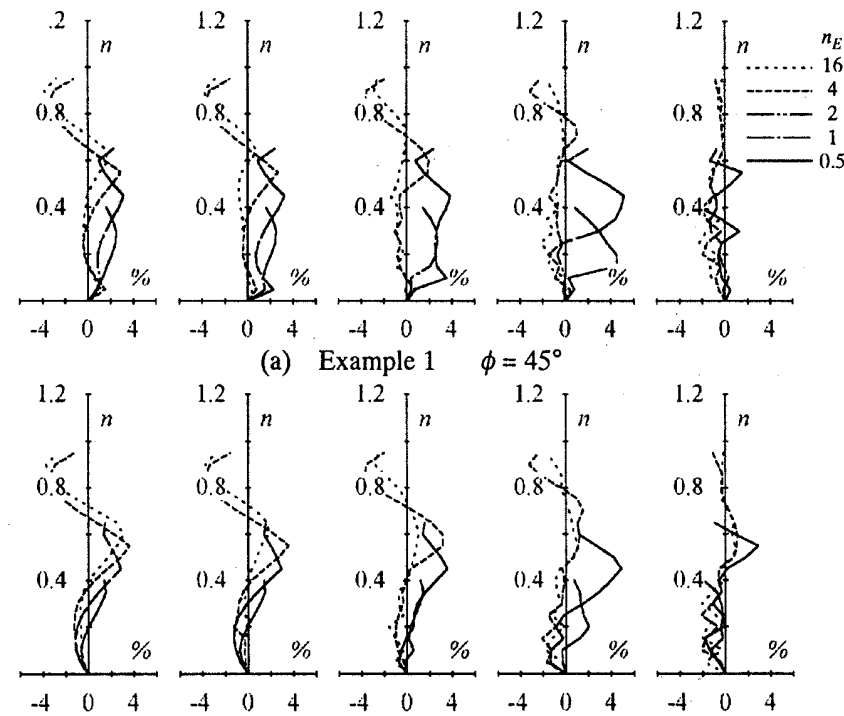

(b) Example $3 \phi=45^{\circ}$
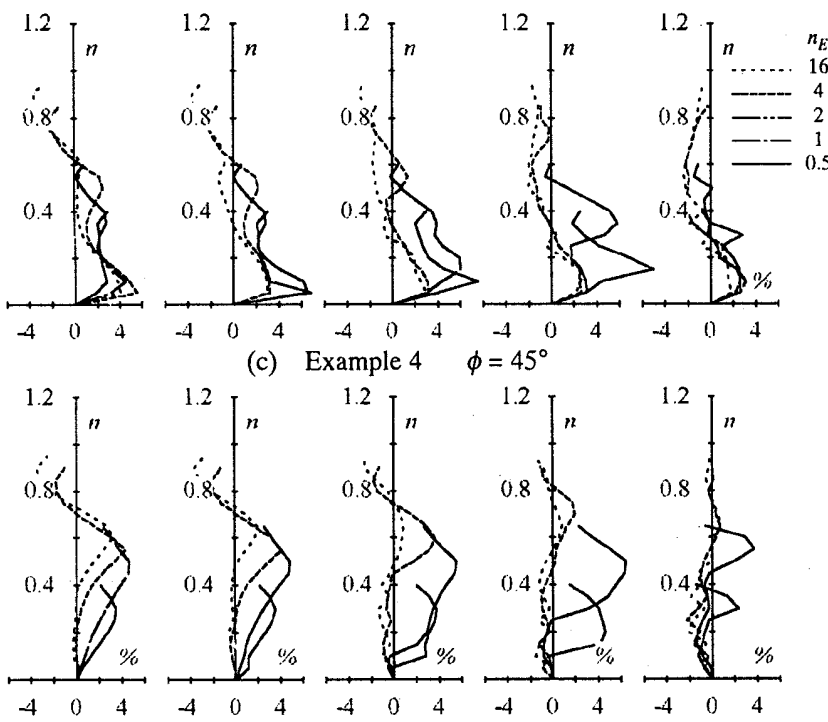

(d) Example $5 \quad \phi=45^{\circ}$

Fig.12 Error estimation Example 2 4

（2000年 1 月 10 日原稿受理， 2000 年 3 月 2 日採用決定） 